How to Cite: Abdimomyn, S., Abduakhytova, D., Atchabarova, A., Turdean, G.L., Tokpayev, R., Kishibayev, K., Kurbatov, A., \& Nauryzbayev, M. (2021). Optimization of the preparation method of a mechanically strong carbon electrode. Bulletin of the University of Karaganda - Chemistry, 104(4), 95-103. https://doi.org/10.31489/2021Ch4/95-103

\title{
CHEMICAL TECHNOLOGY
}

\author{
S. Abdimomyn ${ }^{1}$, D. Abduakhytova ${ }^{1}$, A. Atchabarova ${ }^{1 *}$, G.L. Turdean ${ }^{2}$, \\ R. Tokpayev ${ }^{1}$, K. Kishibayev ${ }^{1}$, A. Kurbatov ${ }^{1}$, M. Nauryzbayev ${ }^{1}$ \\ ${ }^{I}$ Center of Physical Chemical Methods of Research and Analysis, Al-Farabi Kazakh National University, Almaty, Kazakhstan; \\ ${ }^{2}$ Babeş-Bolyai University, Faculty of Chemistry and Chemical Engineering, Cluj-Napoca, Romania \\ (*Corresponding author's e-mail: azhar.atchabarova@mail.ru)
}

\section{Optimization of the preparation method of a mechanically strong carbon electrode}

\begin{abstract}
Nowadays, a strategy for the utilization of secondary resources to obtain valuable components is actual. It will lead to the most rational use of natural resources and environmental protection. Electrochemical methods are perfectly applicable to solve this problem. Electrochemical methods allow concentrating of the target components without preliminary preparation of the raw material. Carbon materials (CM) based on plant and carbon-mineral raw materials are an excellent option as a matrix for obtaining the electrodes, due to their availability, low cost, high specific surface area, and the presence of different functional groups. The lack of theoretical substantiation of the adsorption phenomena on carbon electrodes served as an incentive for the study and development of a method for obtaining a mechanically strong electrode based on modified carbon and polyethylene. The design and mechanical strength of carbon electrodes (CE) are of great importance for the efficiency of purification and extraction of valuable components. In this article, we obtained carbon material from walnut shells by hydrothermal carbonization with further steam-gas activation (the specific surface area is $754.0 \mathrm{~m}^{2} / \mathrm{g}$ ). The structural, physicochemical characteristics of the carbon material, binder, and carrier material were studied by the following methods: scanning electron microscope (SEM), Brunauer-EmmettTeller (BET), thermogravimetric analysis and differential scanning calorymetry (TGA-DSC). The method of hot-pressing is applied for obtaining the carbon electrodes. Using the method of full-factor experiment and steepest ascent, the values of pressure and temperature during pressing and the ratio of carbon material: binder was optimized: $\mathrm{P}=226 \mathrm{~atm} ; \mathrm{T}=90.8^{\circ} \mathrm{C}$; carbon material: binder ratio $=67.5: 32.5 \%$, respectively.
\end{abstract}

Keywords: carbon electrode, full-factor experiment, adsorption, hydrothermal carbonization, carbon material, thermal carbonization, walnut shell, hot-pressing method.

\section{Introduction}

Today, there is a huge trend of environmental and natural resources pollution. Therefore, the transition to recycling strategy of secondary resources is substantial (desalination concentrates, microelectronic scrap, spent oil shale, and industrial wastewater). Rare earth metals such as Pt, V, W, Ge, Mo, Se, Sn, Hf, Nb, La, $\mathrm{Ce}$, etc. are the first economic incentive for mastering separation and concentration methods [1]. The second incentive is the industrial wastewaters of the chemical, metallurgical, and pharmaceutical industries and as a consequence of this, the purification of water resources from the toxic metals $(\mathrm{Cu}, \mathrm{Zn}, \mathrm{Cd}, \mathrm{Co}, \mathrm{Ni}, \mathrm{Pb}, \mathrm{Hg}$, As and $\mathrm{Cr}$ ), surfactants, dyes, organic pollutants, etc. All of these are key economic and environmental problems not only in Kazakhstan but throughout the world.

Hydrometallurgy is a preferred technology for selective extraction and concentration of elements from both low-concentration and wastewater [2]. There are many hydrometallurgical methods that include different effective approaches for separation: selective precipitation, cementation, adsorption, ion flotation, resinbased sorption, liquid extraction, extraction chromatography, biosorption, and electrochemical methods [3-5]. Despite the variety of methods, there are many problems concerning the necessity of high separation and concentration, safety, low energy consumption, economy, negative environmental impact. All of these 
reduce the probability of commercialization $[6,7]$. In particular, the disadvantages for liquid extraction are non-regenerable acids, alkalis, organic solvents, etc; for ion exchange are interfering ligands and metal ions, expenses to the regeneration of ion exchange resins [8]; for biosorption are storage, control of the microorganisms living conditions [9]; for froth flotation are lower selectivity, high cost of flotation reagents and collectors, a large number of tailings [10], etc.

Recently, electrochemical methods have made progress and found wide application in industrial facilities, despite the high energy consumption, low conductivity, and mechanical strength of electrodes, occur side reactions on the electrodes surface, and membrane pollution. For example, electrochemical methods are used in the immobilization of target components on the surface of a solid electrode or in bulk, electrosorption, intercalation, electrodeposition [11]. In comparison with other hydrometallurgical methods, electrochemical methods have the following advantages [12]:

1) reversibility of the process by changing the polarity of the electrode, significantly reducing the consumption of reagents, water, and materials;

2) excluding the secondary waste formation with heavy metals or organic pollutants;

3) adsorption under the influence of current or voltage provides better adsorption capacity, selectivity, and kinetic control, expanding the ability to work in wide $\mathrm{pH}$ ranges using materials of simple composition;

4) simplicity and flexibility of using modular structures and combination with any methods of hydrometallurgy in order to increase selectivity and recovery efficiency;

5) simplicity of combination with renewable energy storage and conversion.

Electrochemical purification and separation methods are based on capacitive accumulation reactions and redox reactions on the surface of electrodes. Consequently, it is necessary to pay great attention to the development of new electrodes with a large specific surface area and a high capacity of the electric double layer (EDL), a fast reaction to ions oxidation - recovery, electrochemical and chemical inertness, obtaining simplicity, cheap and affordable raw materials to achieve mechanically resistant electrodes.

Carbon materials based on plant and carbon-mineral raw are great as initial material for obtaining electrodes because of the availability and cheapness of raw materials, high specific surface area and the presence of functional groups $(-\mathrm{COOH},-\mathrm{COH},-\mathrm{OH}$, etc.). The functional groups contribute to the good hydrophilicity of the surface, the ease of modification in order to improve the electrocatalytic and electro adsorption properties [13]. There are a huge number of modified carbon materials: activated carbons, graphene, carbon nanotubes, nanofibers, carbide-carbon materials, carbon aerogels, etc. [14].

Currently, there is an increase in types, modifications, and methods of carbon electrodes obtaining [15, 16]. These electrodes with mechanical strength possess stability of the stationary potential, good adhesion to a solid substrate. Nevertheless, they have disadvantages: the use of liquid binders reduces the effective specific surface area of carbon electrodes; a percolation threshold decrease leads to blocking of carbon matrix particles and a decrease in electrical conductivity; the presence of an organic binder in the carbon electrode composition leads to an increase of a surface hydrophobicity; the introduction of liquid binder into the electrode composition leads to a mixed stationary potential, which makes impossible evaluating the carbon material contribution to the electrochemical reaction on the carbon electrode surface; an increase in the ohmic and kinetic characteristics of a carbon electrode, etc. [17].

The aim of this work is the optimization of the carbon electrode obtaining method by hot pressing, using the method of full-factor experiment and the steepest ascent.

\section{Experimental}

The study objects are carbon materials $(\mathrm{CM})$ based on walnut shells obtained by the hydrothermal carbonization (HTC) at a temperature of $220-240{ }^{\circ} \mathrm{C}$ for 24 hours with further modification by the steam-gas activation (SGA) at $\mathrm{T}=800-850^{\circ} \mathrm{C}$ for 1 hour [18].

The specific surface area of the sorption materials was determined by the Sorbtometer-M analyzer using the Brunauer-Emmett-Teller (BET) single-point method (Table 1). In this work, the study of the CM by electron microscopy was carried out using a Quanta 3D 200i Dualsystem scanning electron microscope (FEI Company, USA) at the Al-Farabi KazNU "National nanotechnology laboratory of open type".

The selected binder is ultra-fine polyethylene powder (UFPEP), GUR ${ }^{\circ}$, USA. The phase transformations analysis of the binder was carried out on an analyzer "NETZSCH STA 449F3", Germany. Thermogravimetric (TG) and differential scanning calorimetry (DSC) curves were recorded in parallel with increasing temperature. 
The mechanically strong carbon electrode was obtained by hot pressing. The optimal values of the pressure, pressing temperature and the $\mathrm{CM} /$ binder ratio were found. The following intervals of the main independent variables were selected to carry out a full-factor experiment (FFE). There are $\mathrm{T}=25-130^{\circ} \mathrm{C}$; $\mathrm{P}=150-250 \mathrm{~atm}$.; content of UFPEP $=15-30 \%$. In this research, a planning matrix for 2-level 3-factor experiment was used. It is described by 1st order polynomial. The mechanical bending strength of the carbon electrode (bending angle) was measured as a dependent variable. The path-of-steepest-ascent method along the response surface was applied to find the gradient direction of the parameters and reach the stationary region of the response surface. Statistical processing of the full-factor experiment matrix results was tested for reproducibility (3 parallels, Cochran's test), the significance of the regression coefficients (Student's t-test), and the adequacy of the regression equation to this planning matrix (Fisher's test) [19].

\section{Results and Discussion}

Two types of carbon materials were obtained. Sample \#1 by HTC $\left(\mathrm{T}=240^{\circ} \mathrm{C}, \mathrm{t}=24 \mathrm{~h}\right)$ and sample \#2 by HTC $\left(\mathrm{T}=240^{\circ} \mathrm{C}, \mathrm{t}=24 \mathrm{~h}\right)$ with SGA $\left(\mathrm{T}=800-850^{\circ} \mathrm{C}, \mathrm{t}=1 \mathrm{~h}\right)$. The physicochemical properties of the obtained samples are summarized in Table 1.

It was found that carbon materials, based on walnut shells obtained by the HTC with further steam-gas activation, have the best indicators of the iodine number $(82.2 \%)$ and $S_{\text {specific }}=754.0 \mathrm{~m}^{2} / \mathrm{g}$. The results are represented in Table 1. The iodine adsorption number of the samples is one of the main parameters which characterized the pore surface area and, as a consequence, the sorption capacity of coal. Values of iodine adsorption number confirm the numerical values of the materials' specific pore surface area. The obtained SEM images (Fig. 1) indicate the texture of the samples based on plant raw materials is described by a large number of pores on the surface, especially in carbonizates after HTC with SGA.

$\mathrm{Table} 1$

\section{Physicochemical properties of carbon materials}

\begin{tabular}{|c|c|c|c|c|c|}
\hline Sample No. & Humidity, $\%$ & Ash content, $\%$ & $\begin{array}{c}\mathrm{pH} \text { of the aque- } \\
\text { ous extract }\end{array}$ & $\begin{array}{c}\text { Iodine adsorption } \\
\text { number, } \%\end{array}$ & $\mathrm{~S}_{\mathrm{sp}}, \mathrm{m}^{2} / \mathrm{g}$ \\
\hline 1 & 2.05 & 1.05 & 7.9 & 17.6 & 464.9 \\
\hline 2 & 1.07 & 4.38 & 8.3 & $\mathbf{8 2 . 2}$ & $\mathbf{7 5 4 . 0}$ \\
\hline
\end{tabular}

According to the results, a walnut shell obtained by the $\mathrm{HTC}$ method $\left(\mathrm{T}=240{ }^{\circ} \mathrm{C}, \mathrm{t}=24 \mathrm{~h}\right)$ with further SGA $\left(\mathrm{T}=850-900^{\circ} \mathrm{C}, \mathrm{t}=1 \mathrm{~h}\right)$ was selected as the carbon material for obtaining the carbon electrode (CE).

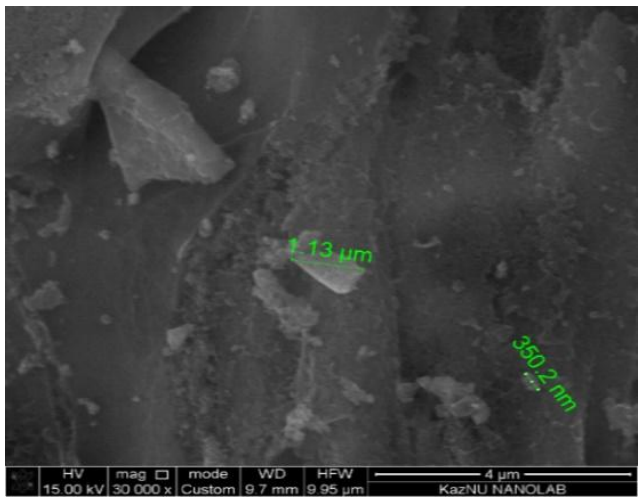

a)

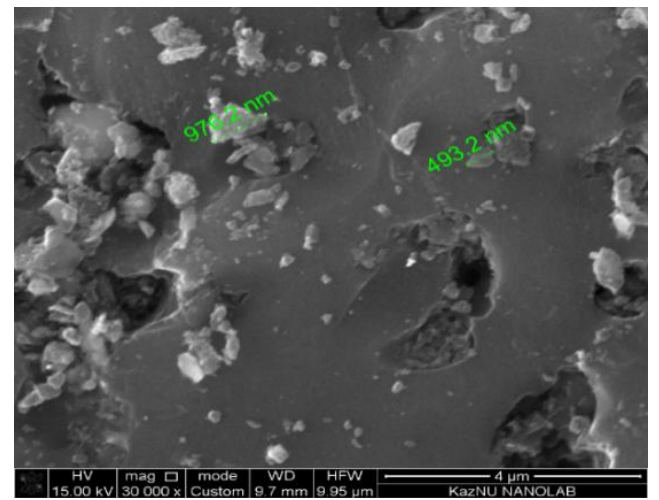

b)

Figure 1. Scanning electron microscopy images of CM No. 1 (a) HTC and No. 2 (b) HTC + SGA. Magnification $\times 30000$

The phase transformations analysis of the binder by the TGA-DSC method are presented in Figure 2. It was found that ultra-fine polyethylene powder (UFPEP) is a homogeneous system with a destruction temperature of $419.6{ }^{\circ} \mathrm{C}$ and a melting point of $125-135^{\circ} \mathrm{C}$ [20].

FFE was used with three independent variables to optimize the CE obtaining method. There are temperature, pressing pressure, and the $\mathrm{CM} /$ binder ratio. Based on preliminary experiments, the parameter values were selected for the FFE matrix (Table 2). 


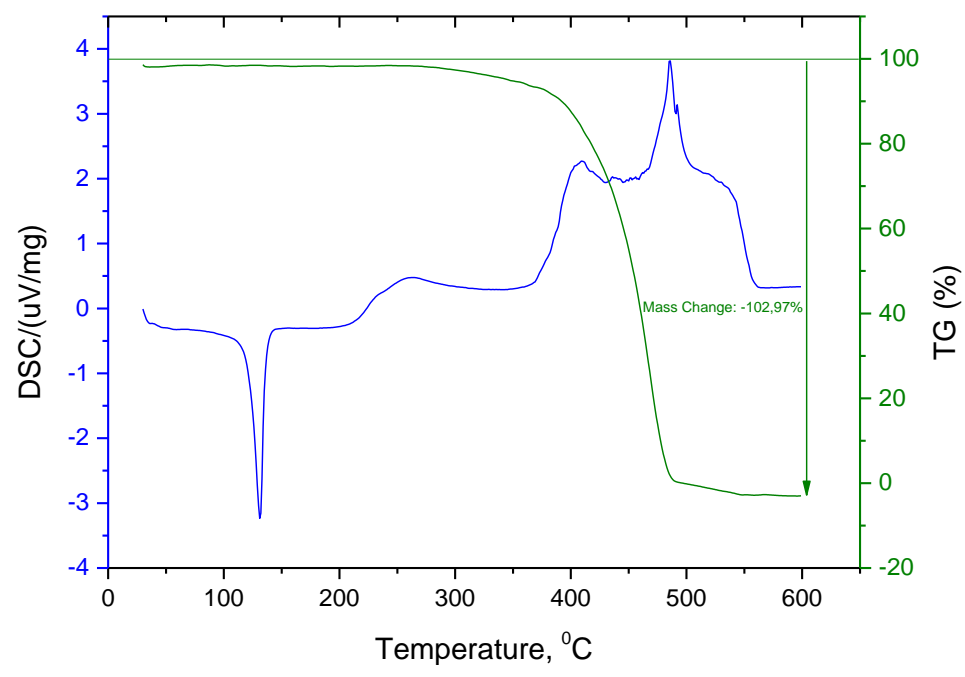

Figure 2. TG and DSC curves of the UFPEP sample

Table 2

\section{Absolute values of the levels of the upper and lower factors}

\begin{tabular}{|c|c|c|c|}
\hline \multirow{2}{*}{ Factor characteristic } & \multicolumn{3}{|c|}{ Value of factors } \\
\cline { 2 - 4 } & $\mathrm{P}$, atm. & CM:UFPEP, $\%$ & $\mathrm{~T},{ }^{\circ} \mathrm{C}$ \\
\cline { 2 - 4 } & $\mathrm{X}_{1}$ & $\mathrm{X}_{2}$ & $\mathrm{X}_{3}$ \\
\hline Upper level $x_{i}=+1$ & 250 & $70: 30$ & 130 \\
\hline Lower level $x_{i}=-1$ & 150 & $85: 15$ & 25 \\
\hline
\end{tabular}

1st order regression equation was obtained using the matrix of a 2-level 3-factor experiment (Table 3):

$$
\mathrm{y}=17.625+2 x_{1}+5.125 x_{2}+4.875 x_{3}+1.125 x_{23}
$$

Ta ble 3

Planning matrix and results of experiments in the study of the CE mechanical bending strength

\begin{tabular}{|c|c|c|c|c|c|c|c|c|c|c|c|}
\hline $\begin{array}{c}\text { Exper. } \\
\text { number }\end{array}$ & $\mathrm{X}_{0}$ & $\mathrm{X}_{1}$ & $\mathrm{X}_{2}$ & $\mathrm{X}_{3}$ & $\mathrm{X}_{1} \mathrm{X}_{2}$ & $\mathrm{X}_{2} \mathrm{X}_{3}$ & $\mathrm{X}_{1} \mathrm{X}_{3}$ & $\mathrm{X}_{1} \mathrm{X}_{2} \mathrm{X}_{3}$ & $\begin{array}{c}\mathrm{y}_{\exp } \\
(\mathrm{av})\end{array}$ & $\sigma^{2}$ & $\mathrm{y}_{\text {calc }}$ \\
\hline $\mathrm{I}$ & $\mathrm{II}$ & $\mathrm{III}$ & $\mathrm{IV}$ & $\mathrm{V}$ & $\mathrm{VI}$ & $\mathrm{VII}$ & $\mathrm{VIII}$ & $\mathrm{IX}$ & $\mathrm{X}$ & $\mathrm{XI}$ & $\mathrm{XII}$ \\
\hline 1 & + & - & - & - & + & + & + & - & 5 & 0.0 & 6.75 \\
\hline 2 & + & + & - & - & - & - & + & + & 13 & 12.5 & 10.8 \\
\hline 3 & + & - & + & - & - & + & - & + & 15 & 0.0 & 14.8 \\
\hline 4 & + & + & + & - & + & - & - & - & 19 & 4.5 & 18.8 \\
\hline 5 & + & - & - & + & + & - & - & + & 13 & 12.5 & 14.3 \\
\hline 6 & + & + & - & + & - & + & - & - & 20 & 0.0 & 18.3 \\
\hline 7 & + & - & + & + & - & - & + & - & 30 & 0.0 & 26.8 \\
\hline 8 & + & + & + & + & + & + & + & + & 28 & 12.5 & 30.8 \\
\hline
\end{tabular}

The reproducibility of the results and the adequacy of the simulation model to the experimental data on mechanical strength have been assessed by Cochran's, Student's, and Fisher's tests, respectively (Table 4) [19].

Table 4

Assessment of the experimental results reproducibility and the adequacy of the computational model

\begin{tabular}{|c|c|c|c|}
\hline № & Experimental value & \multicolumn{2}{c|}{ Table value[19] } \\
\hline 1 & \multicolumn{2}{|c|}{ Cochran's test $\left(\mathrm{G}_{\mathrm{t}}(\beta=0,1\right.$ at $\left.\mathrm{n}=3 \mathrm{~N}=8)>\mathrm{G}_{\text {exp }}\right)$} \\
\hline & 0.298 & & 0.57 \\
\hline 2 & \multicolumn{3}{|c|}{ Fisher's test $\left(\mathrm{F}_{\text {exp }}<\mathrm{F}_{\text {table }}\left(\mathrm{f}_{1}=4, \mathrm{f}_{2}=16\right)\right)$} \\
\hline & 1.590 & & 3.80 \\
\hline
\end{tabular}


The given above mathematical model showed that the second (CM:UFPEP, \%) and third (pressing temperature) variables have the greatest influence on the electrode mechanical strength. The pressing pressure value is 2.5 times less. According to Fisher's test, the adequacy of the regression equation is established. It describes the response surface.

For the mathematical description of the extremum stationary region, the steepest ascent method was applied. The experimental and the corresponding calculated values of $\mathrm{y}_{\mathrm{i}}$ are presented in Table 6 . The interval of variation was determined by differentiating equation 1 :

$$
\begin{aligned}
& b_{1}=2.000 \\
& b_{2}=5.125 \\
& b_{3}=4.875
\end{aligned}
$$

Table 5

The value of variables in the study of the $\mathrm{CE}$ mechanical bending strength

\begin{tabular}{|l|c|c|c|}
\hline \multicolumn{1}{|c|}{ Factor } & P, atm. & CM:UFPEP, $\%$ & $\mathrm{~T},{ }^{\circ} \mathrm{C}$ \\
\hline Code designation & $\mathrm{X}_{1}$ & $\mathrm{X}_{2}$ & $\mathrm{X}_{3}$ \\
\hline Main level $\mathrm{X}_{\mathrm{i} 0}=0$ & 200.0 & $77.5: 22.5$ & 77.5 \\
\hline Variation interval $\Delta \mathrm{X}_{\mathrm{i}}$ & 13.0 & 5.0 & 6.65 \\
\hline
\end{tabular}

Plan and results of the experiment carried out by the steepest ascent method

\begin{tabular}{|l|c|c|c|c|c|}
\hline \multicolumn{1}{|c|}{ Factors } & $\mathrm{X}_{1}$ & $\mathrm{X}_{2}$ & $\mathrm{X}_{3}$ & $\mathrm{Y}_{\text {calc }}$ & $\mathrm{Y}_{\text {exp }}$ \\
\hline Coefficient $\mathrm{b}_{\mathrm{i}}$ & 2 & 5.125 & 4.875 & & \\
\cline { 1 - 3 } Variation step & 13 & 5.00 & 6.65 & & 18.3 \\
\hline Starting point & 200 & 22.50 & 77.50 & 20.0 & 24.7 \\
\hline Realized experience I & 213 & 27.50 & 84.15 & 22.2 & $\underline{\mathbf{2 5 . 8}}$ \\
\hline Realized experience II & $\mathbf{2 2 6}$ & $\underline{\mathbf{3 2 . 5 0}}$ & $\mathbf{9 0 . 8 0}$ & 26.7 & 22.3 \\
\hline Realized experience III & 239 & 37.50 & 97.45 & 31.3 & 20.4 \\
\hline Realized experience IV & 252 & 42.40 & 104.10 & 35.9 & 20.2 \\
\hline Realized experience V & 265 & 47.50 & 110.75 & 40.4 & \\
\hline
\end{tabular}

Based on the coefficients values the gradient equation for this system is derived:

$$
\operatorname{gradY}=2 i+5.125 j+4.875 k
$$

On the basis of this equation, the direction to the stationary region of the extremum is found by the steepest ascent method. The largest value of the coefficient $-\mathrm{b}_{2}=5.125$ was taken as the basic factor $\mathrm{X}_{2}$. The step for which was set $\delta X_{2}=5$. Then the variation steps were calculated for the remaining factors (Table 5):

$$
\begin{gathered}
\delta \mathrm{X}_{1}=\frac{2 \cdot 50 \cdot 5}{5.125 \cdot 7.5}=13 ; \\
\delta \mathrm{X}_{3}=\frac{4.875 \cdot 52.5 \cdot 5}{5.125 \cdot 7.5}=6.65 .
\end{gathered}
$$

In order to assess the direction to the stationary extremum region, Student's t-test and Fisher's test were used for two independent samples (Table 7).

Assessment of the adequacy approximated and experimental dependent variable

\begin{tabular}{|c|cc|c|}
\hline$\#$ & Experimental value & \multicolumn{1}{c|}{ Table value [19] } \\
\hline 1 & \multicolumn{3}{|c|}{ Fisher's test $\left(\mathrm{F}_{\exp }<\mathrm{F}_{\text {table }}\left(\mathrm{f}_{1}=5, \mathrm{f}_{2}=5\right)\right)$} \\
\hline & 4.54 & & 5.05 \\
\hline 2 & \multicolumn{3}{|c|}{ Student's t-test $\left(\mathrm{t}_{\exp }<\mathrm{t}_{\text {table }}(\mathrm{N}=10, \mathrm{P}=0,95)\right.$} \\
\hline & 2.19 & & 2.23 \\
\hline
\end{tabular}


Based on the experiment results of the steepest ascent method, it was found that the third experiment did not illustrate an increase of CE mechanical strength in comparison with the second experiment. The experimental $\mathrm{Y}_{\text {exp }}=22.3$ and theoretical $\mathrm{Y}_{\text {calc }}=31.3$ values have a significant difference; therefore, further study in this direction does not make sense (Table 6).

\section{Conclusion}

In this paper, carbon materials based on walnut shells have been obtained by the hydrothermal carbonization method and modification by the steam-gas activation method. Their physicochemical and structural characteristics have been studied and optimized. The best value of $S_{\text {specific }}$ is $754.0 \mathrm{~m}^{2} / \mathrm{g}$ and the iodine adsorption number is $82.2 \%$. The function of the extremum stationary region was achieved using a full-factor experiment and the steepest ascent method. The mathematical approach made possible to find the direction of the function gradient and to reach the region of the stationary extremum under the following experimental conditions:

$$
\mathrm{P}=226 \mathrm{~atm} . ; \mathrm{T}=90.8^{\circ} \mathrm{C} ; \mathrm{UFPEP}: \mathrm{CM}=32.5: 67.5 \% \text {. }
$$

The steepest ascent method will allow optimizing the mechanical strength of the CE depending on 3 independent factors.

\section{Acknowledgments}

This research was funded by the Science Committee of the Ministry of Education and Science of the Republic of Kazakhstan (Grant No. AP08957598 "The use of electrochemical methods for studying adsorption to characterize new carbon materials").

\section{References}

1 Perez J.P. Progress in hydrometallurgical technologies to recover critical raw materials and precious metals from lowconcentrated streams / J.P. Perez, K.H. Folens, K. Leus, F. Vanhaecke, P. Van Der Voort, G. Du Laing // Resources, Conservation and Recycling. - 2019. - Vol. 142. - P. 177-188. DOI 10.1016/j.resconrec.2018.11.029

2 Sethurajan M. Recent advances on hydrometallurgical recovery of critical and precious elements from end of life electronic wastes - a review / M. Sethurajan, E.D. van Hullebusch, D. Fontana, A. Akcil, H. Deveci, B. Batinic, et al. // Critical Reviews in Environmental Science and Technology. - 2019. - Vol. 49, Is. 3. - P. 212-275.https://doi.org/10.1080/10643389.2018.1540760

3 Ramachandra Rao S. Resource Recovery and Recycling from Metallurgical Wastes / S. Ramachandra Rao. - Montreal: Elsevier, 2006. - 508 p.

4 Ahluwalia S.S. Microbial and plant derived biomass for removal of heavy metals from wastewater / S.S. Ahluwalia, D. Goyal // Bioresource Technology. — 2007. — Vol. 98. — P. 2243-2257. DOI: 10.1016/j.biortech.2005.12.006

5 Qi D. Hydrometallurgy of Rare Earths / D. Qi. - Amsterdam: Elsevier, 2018. — P. 631-669.

$6 \mathrm{Wu}$ T. Amidoxime-Functionalized Macroporous Carbon Self-Refreshed Electrode Materials for Rapid and High-Capacity Removal of Heavy Metal from Water / T. Wu, C. Liu, B. Kong, J. Sun, Y. Gong, K. Liu, et al. // ACS Central Science. - 2019. Vol. 5. - P. 719-726. DOI: 10.1021/acscentsci.9b00130

7 Eskandari E. A review on polyaniline-based materials applications in heavy metals removal and catalytic processes / E. Eskandari, M. Kosari, M.H. Davood Abadi Farahani, N.D. Khiavi, M. Saeedikhani, R. Katal, et al. // Separation and Purification Technology. — 2020. — Vol. 231. - P. 1-27. DOI: 10.1016/j.colsurfa.2021.126274

8 Viel P. New concept to remove heavy metals from liquid waste based on electrochemical pH-switchable immobilized ligands / P. Viel, L. Dubois, J. Lyscawa, M. Salle, S.Palacin // Applied Surface Science. — 2007. — Vol. 253. — P. 3263-3269. DOI 10.1016/j.apsusc.2006.07.022

9 Bonificio W.D. Rare-Earth Separation Using Bacteria / W.D. Bonificio, D.R. Clarke // Environmental Science and Technology Letters. - 2016. - Vol. 3. - P. 180-184. DOI: 10.1021/acs.estlett.6b00064

10 Irannajad M. Surface dissolution-assisted mineral flotation: A review / M. Irannajad, O. Salmani Nuri, A. Mehdilo // Journal of Environmental Chemical Engineering. — 2019. — Vol. 7. — P. 103050. https://doi.org/10.1016/j.jece.2019.103050

11 Anjum N.A. Enhancing Cleanup of Environmental Pollutants / N.A. Anjum, S.S. Gill, N. Cham. Tuteja. - New York: Springer International Publishing, 2017. - P. 327.

12 Maarof H.I. Recent trends in removal and recovery of heavy metals from wastewater by electrochemical technologies / H.I. Maarof, W.M.A.W. Daud, M.Kh. Aroua // Reviews in Chemical Engineering. - 2017. - Vol. 33 . - P. 359386.DOI: https://doi.org/10.1515/revce-2016-0021

13 Abioye A.M. Advancement in the Production of Activated Carbon from Biomass Using Microwave Heating / A.M. Abioye, F. Nasir Ani, J. Bahru // Jurnal Teknologi. — 2017. — Vol. 79. — P. 2180-3722.DOI: https://doi.org/10.11113/jt.v79.7249

14 Liu C.F. Carbon materials for high-voltage supercapacitors / C.F. Liu, Y.C. Liu, T.Y. Yi, C.C. Hu // Carbon. — 2019. Vol. 145. - P. 529-548. https://doi.org/10.1016/j.carbon.2018.12.009 
15 Abioye A.M. Recent development in the production of activated carbon electrodes from agricultural waste biomass for supercapacitors: A review / A.M. Abioye, F.N. Ani // Renewable and Sustainable Energy Reviews. — 2015. — Vol. 52. — P. 12821293. https://doi.org/10.1016/j.rser.2015.07.129

16 Borenstein A. Carbon-based composite materials for supercapacitor electrodes: A review / A.Borenstein, O.Hanna, R. Attias, S.Luski, T.Brousse, D.Aurbach // Journal of Materials Chemistry A. - 2017. - Vol. 5. — P. 12653-12672. DOI: 10.1039/C7TA00863E

17 Тарасевич М.Р. Электрохимия углеродных материалов / М.Р. Тарасевич. — М.: Наука,1984. — С. 218-223.

18 AtchabarovaA.A. New electrodes prepared from mineral and plant raw materials of Kazakhstan / A.A. Atchabarova, R.R. Tokpayev, A.T. Kabulov, S.V. Nechipurenko, R.A. Nurmanova, S.A. Yefremov, etal.// Eurasian Chemico-Technological Journal. — 2016. - Vol. 18. — P. 141-147. DOI: 10.18321/ectj440

19 Берикашвили В.Ш. Статистическая обработка данных, планирование эксперимента и случайные процессы / В.Ш. Берикашвили, С.П. Оськин. - М.: Юрайт, 2019. - 162 с.

20 Ершова О.В. Использование метода дифференциальной сканирующей калориметрии и термогравиметрического анализа для определения состава и температуры деструкции вторичных полимеров / О.В. Ершова, М.А. Мельниченко // Успехи современного естествознания. - 2015. - № 11. - С. 26-30.

\author{
С.Қ. Әбдімомын, Д.А. Абдуахытова, А.А. Атчабарова, Г.Л. Турдеан, \\ Р.Р. Токпаев, К.К. Кишибаев, А.П. Курбатов, М.К. Наурызбаев
}

\title{
Механикалық берік көміртекті электродты дайындау әдісін оңтайландыру
}

Қазіргі әлемде табиғи ресурстарды ұтымды пайдалануға және қоршаған ортаны қорғауға әкелетін құнды компоненттерді алу мақсатында қайталама ресурстарды жою стратегиясы байқалып отыр. Мәселені шешу үшін шикізатты алдын-ала дайындамай-ақ мақсатты компоненттерді іріктеп шоғырландыруға мүмкіндік беретін электрохимиялық әдістер өте жақсы қолданылады. Өсімдік және минералды шикізатқа негізделген көміртекті материалдар (КМ) қол жетімділігіне, арзандығына, бетінің жоғары меншікті ауданына және әртүрлі функционалды топтардың болуына байланысты электродтарды өндіруге арналған матрица ретінде тамаша нұсқа болып табылады. Көмір электродтарындағы адсорбция құбылыстарын теориялық негіздеудің жетіспеушілігі модификацияланған көміртегі мен полиэтилен негізінде механикалық күшті электрод жасау әдісін зерттеуге және дамытуға түрткі болды. Көміртекті электродтардың (КМ) дизайны мен механикалық беріктігі тазартудың, құнды компоненттерді алудың тиімділігі үшін үлкен маңызға ие. Мақалада авторлар грек жаңғағының қабығынан гидротермальды карбонизация және бу газды белсендірлеу әдісімен көміртекті материал алған, оның бетінің ауданы 754,0 м²/г құрады. Көміртек материалының, байланыстырушының және КМ субстратының материалының құрылымдық, физика-химиялық сипаттамалары келесі әдістермен зерттелді: СЭМ, БЭТ, ТГТ-ДСК. Көміртекті электродтарды жасау үшін ыстық престеу әдісі қолданылды. Толық факторлы эксперимент және тік көтерілу әдісін қолдана отырып, қысым мен температураның мәндері және көміртекті материал: байланыстырушы қатынасы оңтайландырылды: $\mathrm{P}=226$ атм.; $\mathrm{T}=90,8^{\circ} \mathrm{C}$; көміртекті материал: байланыстырушы қатынасы $=$ $=67,5: 32,5 \%$.

Кілm сөздер: көміртекті электрод, толық факторлы эксперимент, адсорбция, гидротермальды карбонизация, көміртекті материал, термальды карбонизация, грек жаңғағы, ыстық престеу әдісі.

\section{С.К. Абдимомын, Д.А. Абдуахытова, А.А. Атчабарова, Г.Л. Турдеан, Р.Р. Токпаев, К.К. Кишибаев, А.П. Курбатов, М.К. Наурызбаев \\ Оптимизация метода изготовления механически прочного углеродного электрода}

\begin{abstract}
В современном мире наблюдается стратегия по утилизации вторичных ресурсов с целью получения из них ценных компонентов, которая приведет к наиболее рациональному использованию природных ресурсов и охране окружающей среды. Для решения проблемы отлично применимы электрохимические методы, которые позволяют селективно концентрировать целевые компоненты без предварительной подготовки сырья. Углеродные материалы (УМ) на основе растительного и минерального сырья являются отличным вариантом в качестве матрицы для изготовления электродов, вследствие доступности, дешевизны, высокой удельной площади поверхности и наличия разных функциональных групп. Недостаток теоретического обоснования явлений адсорбции на угольных электродах послужил стимулом для изучения и разработки способа изготовления механически прочного электрода на основе модифицированного углерода и полиэтилена. Конструкция и механическая прочность углеродных электродов (УЭ) имеют огромное значение для эффективности очистки,
\end{abstract}


извлечения ценных компонентов. В статье описано получение углеродного материала из скорлупы грецкого ореха методом гидротермальной карбонизации с дальнейшей парогазовой активацией, с удельной площадью поверхности 754,0 м²/г. Структурные, физико-химические характеристики углеродного материала, связующего и материала подложки УЭ изучены следующими методами: СЭМ, БЭТ, ТГА-ДСК. Для изготовления углеродных электродов применен метод горячего прессования. С помощью метода полнофакторного эксперимента и крутого восхождения оптимизированы значения давления и температуры при прессовании и соотношении углеродный материал : связующее: $\mathrm{P}=226$ атм.; Т $=90,8{ }^{\circ} \mathrm{C}$; соотношение УМ : связующее $=67,5: 32,5 \%$ соответственно.

Ключевые слова: углеродный электрод, полнофакторный эксперимент, адсорбция, гидротермальная карбонизация, углеродный материал, термальная карбонизация, скорлупа грецкого ореха, метод горячего прессования.

\section{References}

1 Perez, J.P., Folens, K.H., Leus, K., Vanhaecke, F., Van Der Voort, P., \& Du Laing, G. (2019). Progress in hydrometallurgical technologies to recover critical raw materials and precious metals from low-concentrated streams.Resources, Conservation and Recycling, 142, 177-188. DOI 10.1016/j.resconrec.2018.11.029

2 Sethurajan, M., van Hullebusch, E.D., Fontana, D., Akcil, A., Deveci, H., \& Batinic, B., et al. (2019). Recent advances on hydrometallurgical recovery of critical and precious elements from end of life electronic wastes - a review. Critical Reviews in Environmental Science and Technology, 49, 212-275. https://doi.org/10.1080/10643389.2018.1540760

3 Ramachandra Rao, S. (2006). Resource Recovery and Recycling from Metallurgical Wastes. Montreal: Elsevier.

4 Ahluwalia, S.S., \& Goyal, D. (2007). Microbial and plant derived biomass for removal of heavy metals from wastewater. Bioresource Technology, 98, 2243-2257. DOI: 10.1016/j.biortech.2005.12.006

5 Qi, D. (2018). Hydrometallurgy of Rare Earths. Amsterdam: Elsevier.

6 Wu, T., Liu, C., Kong, B., Sun, J., Gong, Y., \& Liu, K., et al. (2019). Amidoxime-Functionalized Macroporous Carbon SelfRefreshed Electrode Materials for Rapid and High-Capacity Removal of Heavy Metal from Water. ACS Central Science, 5, 719-726. DOI: $10.1021 /$ acscentsci.9b00130

7 Eskandari, E., Kosari, M., Davood Abadi Farahani, M.H., Khiavi, N.D., Saeedikhani, M., \& Katal, R., et al. (2020). A review on polyaniline-based materials applications in heavy metals removal and catalytic processes. Separation and Purification Technology, 231, 1-27. DOI: 10.1016/j.colsurfa.2021.126274

8 Viel, P., Dubois, L., Lyscawa, J., Salle, M., \& Palacin, S. (2007). New concept to remove heavy metals from liquid waste based on electrochemical pH-switchable immobilized ligands. Applied Surface Science, 253, 3263-3269. DOI 10.1016/j.apsusc.2006.07.022

9 Bonificio, W.D., \& Clarke, D.R. (2016). Rare-Earth Separation Using Bacteria. Environmental Science and Technology Letters, 3, 180-184. DOI: 10.1021/acs.estlett.6b00064

10 Irannajad, M., Salmani Nuri, O., \& Mehdilo, A. (2019). Surface dissolution-assisted mineral flotation: A review. Journal of Environmental Chemical Engineering, 7, 103050. https://doi.org/10.1016/j.jece.2019.103050

11 Anjum N.A., Gill S.S., \& Tuteja N. Cham. (2017). Enhancing Cleanup of Environmental Pollutants. New York: Springer International Publishing.

12 Maarof, H.I., Daud, W.M.A.W., \& Aroua, M.K.D. (2017). Recent trends in removal and recovery of heavy metals from wastewater by electrochemical technologies. Reviews in Chemical Engineering, 33, 359-386. DOI: https://doi.org/10.1515/revce2016-0021

13 Abioye, A.M., Nasir Ani, F., \& Bahru, J. (2017). Advancement in the Production of Activated Carbon from Biomass Using Microwave Heating. Jurnal Teknologi, 79, 2180-3722. DOI: https://doi.org/10.11113/jt.v79.7249

14 Liu, C.F., Liu, Y.C., Yi, T.Y., \& Hu, C.C. (2019). Carbon materials for high-voltage supercapacitors. Carbon, 145, 529-548. https://doi.org/10.1016/j.carbon.2018.12.009

15 Abioye, A.M., \& Ani, F.N. (2015). Recent development in the production of activated carbon electrodes from agricultural waste biomass for supercapacitors: A review. Renewable and Sustainable Energy Reviews, 52, $1282-1293$. https://doi.org/10.1016/j.rser.2015.07.129

16 Borenstein, A., Hanna, O., Attias, R., Luski, S., Brousse, T., \& Aurbach, D. (2017). Carbon-based composite materials for supercapacitor electrodes: A review. Journal of Materials Chemistry A, 5, 12653-12672. DOI: 10.1039/C7TA00863E

17 Tarasevich, M.R. (1984). Elektrokhimiia uglerodnykh materialov [Electrochemistry of Carbon Materials]. Moscow: Nauka [in Russian].

18 Atchabarova, A.A., Tokpayev, R.R., Kabulov, A.T., Nechipurenko, S.V., Nurmanova, R.A., \& Yefremov, S.A., et al. (2016). New electrodes prepared from mineral and plant raw materials of Kazakhstan. Eurasian Chemico-Technological Journal, 18, 141147. DOI: $10.18321 /$ ectj440

19 Berikashvili, V.Sh., \& Oskin, S.P. (2019). Statisticheskaia obrabotka dannykh, planirovanie eksperimenta i sluchainye protsessy [Statistical data processing, experiment planning and random processes]. Moscow: Yurait [in Russian]. 
20 Ershova, O.V., \& Melnichenko, M.A. (2015). Ispolzovanie metoda differentsialnoi skaniruyushchei kalorimetrii i termogravimetricheskogo analiza dlia opredeleniia sostava i temperatury destruktsii vtorichnykh polimerov [Using the method of differential scanning calorimetry and thermogravimetric analysis to determine the composition and temperature of degradation secondary polymers]. Uspekhi sovremennogo estestvoznaniia - Advances in modern natural science, 11, 26-30 [in Russian].

\section{Information about authors}

Abdimomyn Saken Kynabekuly - Master student, Junior Researcher of the Center of Physical Chemical Methods of Research and Analysis of Al-Farabi Kazakh National University, Tole bi str., 96A, 050000, Almaty, Kazakhstan; e-mail: abdimomyn03@ gmail.com, https://orcid.org/0000-0002-5985-9050

Abduakhytova Dinara Aktaikyzy — PhD student, Researcher of the Center of Physical Chemical Methods of Research and Analysis of Al-Farabi Kazakh National University, Tole bi str., 96A, 050000, Almaty, Kazakhstan; e-mail: abduakhytova@mail.ru, https://orcid.org/0000-0002-4316-0755

Atchabarova Azhar Aidarovna (corresponding author) - PhD, Senior Researcher, Head of Laboratory of Hydroelectrometallurgical Processes, Center of Physical Chemical Methods of Research and Analysis of al-Farabi Kazakh National University, Tole bi str., 96A, 050000, Almaty, Kazakhstan; e-mail: azhar.atchabarova@mail.ru, https://orcid.org/0000-0002-4600-2728

Turdean Graziella Liana - Professor, Dr. habil. eng., Head of Department of Chemical Engineering, Babes-Bolyai University, Faculty of Chemistry and Chemical Engineering; 11, Arany Janos St., 400028 Cluj-Napoca, Romania; e-mail: graziella.turdean@ubbcluj.ro, https://orcid.org/0000-0003-1273-6878

Tokpayev Rustam Rishatovich - PhD, Leading Researcher, Head of Laboratory of Sorption and Catalytic Processes, Center of Physical Chemical Methods of Research and Analysis of al-Farabi Kazakh National University, Tole bi str., 96A, 050000, Almaty, Kazakhstan; e-mail: rustamtokpaev@mail.ru, https://orcid.org/0000-0002-0117-4454

Kishibayev Kanagat Kazhmukanovich - PhD, Senior Researcher of the Center of Physical Chemical Methods of Research and Analysis of Al-Farabi Kazakh National University, Tole bi str., 96A, 050000, Almaty, Kazakhstan; e-mail: kanagat_kishibaev@mail.ru, https://orcid.org/0000-0003-1590-5243

Kurbatov Andrey Petrovich - Professor, Doctor of chemical sciences, Chief Researcher, Head of Electrochemical Production Technologies Laboratory, Center of Physical Chemical Methods of Research and Analysis of al-Farabi Kazakh National University, Tole bi str., 96A, 050000, Almaty, Kazakhstan; email: apkurbatov@gmail.com, https://orcid.org/0000-0003-1883-310X

Nauryzbayev Mikhail Kassymovich - Professor, Doctor of technical sciences, Chief Researcher of the Center of Physical Chemical Methods of Research and Analysis of Al-Farabi Kazakh National University, Tole bi str., 96A, 050000, Almaty, Kazakhstan; e-mail: nauryzbaev@cfhma.kz, https://orcid.org/00000002-6781-6464 